Eur. J. Clin. Chem. Clin. Biochem.

Vol. 32, 1994, pp. 479-483

(C) 1994 Walter de Gruyter \& Co. Berlin - New York

\title{
Optimisation of a New Continuous UV Assay for the Determination of Blood Coagulation Factor XIII Activity in Human Plasma
}

\author{
By M. Heins, Urte Fahron, W. Withold and W. Rick \\ Institut für Klinische Chemie und Laboratoriumsdiagnostik, Medizinische Einrichtungen der \\ Heinrich-Heine-Universität, Düsseldorf, Germany
}

(Received October 13, 1993/March 21, 1994)

Summary: The new photometric assay described by Fickenscher et al. (Thromb. Haemostas. 65 (1991) 535-540) for the determination of factor XIII facilitates the diagnosis of factor XIII deficiency. In spite of easy handling, this test should be used critically. Patients with hyperfibrinogenaemia showed factor XIII activities of less than $20 \%$, whereas with an optimized assay we found normal factor XIII values. Also, the use of a fixed period of incubation for the analysis is questionable, because the period of constant reaction rate occurs earlier and is shorter with high factor XIII activities and later and longer with low factor XIII activities. A linear relation between factor XIII activity and signal only exists up to $80 \%$ of activity.

In some plasma samples from patients with hyperfibrinogenaemia the factor XIII determination actually shows decreased values for factor XIII. During the reaction, a fibrin clot is formed. The resulting turbidity simulates an increase in absorbance so that NADH consumption is apparently decreased. In six patients with hyperfibrinogenaemia $(8.1-9.4 \mathrm{~g} / \mathrm{l})$, a factor XIII activity of $26 \mathrm{U} / 1$ or less was determined. Using $50 \mu \mathrm{l}$ instead of $100 \mu \mathrm{l}$ sample volume, $50 \%(3 / 6)$ of the patients showed a normal factor XIII activity $(80-96 \mathrm{U} / 1)$, whereas $50 \%(3 / 6)$ values of 6-15 U/1 were found. In our modified assay we measured normal factor XIII activities (72-151 U/l) in all 6 patients. The procedure is optimized by reducing the sample volume from $100 \mu 1$ to $50 \mu \mathrm{l}$. The concentration of the fibrin aggregation inhibitor is raised from $0.5 \mathrm{~g} / 1$ to $1.0 \mathrm{~g} / 1$ in the test solution, and the period of constant reaction rate is used for the determination. Enzyme activity is expressed in $U / 1\left(37^{\circ} \mathrm{C}\right)$. Optimized in this way, the assay shows a linear relationship between the decrease of absorbance and factor XIII activity up to more than $128 \mathrm{U} / \mathrm{l}$, corresponding to $140 \%$. Plasma samples with high concentrations of fibrinogen can be analysed without problems. Precision was $2.3 \%$ in series and $2.8 \%$ from day to day, using a control plasma with $81 \mathrm{U} / \mathrm{l}$; for a control plasma with $35 \mathrm{U} / \mathrm{l}$, the respective values were $4.9 \%$ and $5.8 \%$. In apparently healthy 100 persons a reference interval of factor XIII activity was established from 66 to $142 \mathrm{U} / 1$ or 73 to $155 \%$.

\section{Introduction}

Earlier methods for the determination of coagulation factor XIII activity in plasma were time consuming, gave only semiquantitative results, or they involved many processing steps, often with a pretreatment of the sample $(1-4)$. Continuous photometric tests for the determination of factor XIII in plasma have already been described. In these assays, the clotting of the fibrin, formed by proteolysis of fibrinogen in the sample by thrombin, has to be inhibited. Otherwise, the increasing turbidity of the reaction mixture results in falsely low factor XIII activities. These methods start with the precipitation of fibrinogen from the sample, for example using bentonite as a precipitating agent. As factor XIII is bound to fibrinogen, and the thrombin-mediated activation of factor XIII is enhanced in the presence of fibrinogen, the precipitation of this protein can lead to decreased factor XIII values (5-10). A new photometric test for the determination of factor XIII activity was therefore recently described, in which fibrinogen is not 
precipitated, but a fibrin aggregation inhibitor (gly-proarg-pro-ala-amide) is added to the system (11).

We have analysed the performance of this assay. The test was optimized to analyse samples from patients with hyperfibrinogenaemia and factor XIII activities of more than $80 \%$.

\section{Materials and Methods}

\section{Plasma samples}

Blood specimens were obtained by venipuncture in $0.129 \mathrm{~mol} / \mathrm{l}$ sodium citrate solution $\mathrm{pH} 6.05$ ( 1 part of sodium citrate and 9 parts of blood). After centrifugation for 15 minutes at $2000 \mathrm{~g}$ and room temperature, citrate plasma was separated. Samples were stored at $-20^{\circ} \mathrm{C}$ for not longer than 4 weeks.

\section{Reagents}

Berichrom Factor XIII assay (lot: 24710; Behringwerke); Bovine fibrinogen F XIII-free (lot: 43; Behringwerke); pure F XIII from human plasma (lot: 089791; Calbiochem); fibrin aggregation inhibitor gly-pro-arg-pro-ala-amide, 86\% (lot: 64HSO4; Behringwerke); CTS standard plasma (lot: 511513A; Behringwerke); CTS control plasma N (lot: 511612A; Behringwerke); CTS control plasma P (lot: 512612A; Behringwerke); sodium chloride solution, $154 \mathrm{mmol} / \mathrm{l}$ in double distilled water.

\section{Instrumentation}

Spectrophotometer Lambda 5 (Perkin-Elmer) fully mechanised with cuvette exchange station which can be temperature controlled at $37 \pm 0.2^{\circ} \mathrm{C}$ (water bath) and plotter.

\section{Statistical analysis}

The Kolmogoroff-Smirnow-fitting test and Lilliefors limits were used to examine whether the reference values are normally distributed $(12-14)$.

\section{Methods}

\section{Assay according to Fickenscher}

The reaction mixture was reconstituted in double distilled water according to the manufacturer's instructions and incubated in $1 \mathrm{ml}-$ aliquots in reaction tubes at $37^{\circ} \mathrm{C}$ (water bath). After addition of $100 \mu \mathrm{l}$ sample and mixing in the reaction tube the measurement was carried out in semimicro cuvettes prewarmed to $37^{\circ} \mathrm{C}$. Absorbance differences per minute $(\triangle \mathrm{A} / \mathrm{min})$ were monitored continuously over a period of up to 40 minutes. In this time the period of constant reaction rate was determined in which the change of absorbance per minute did not differ by more than $0.005 / \mathrm{min}$. The catalytic concentration was calculated according to Lambert-BeerBouguer's law (15):

$$
b[\mathrm{U} / \mathrm{l}]=\frac{\Delta A / \mathrm{min}}{630 \cdot 0.01 \cdot 10^{-3}} \cdot \frac{1.1 \cdot 10^{-3}}{0.1 \cdot 10^{-3}}=\Delta A / \mathrm{min} \cdot 1746
$$

where:

$$
\begin{aligned}
1.1 \cdot 10^{-3}= & \text { total volume in cuvette, in litres } \\
0.1 \cdot 10^{-3}= & \text { volume of sample, in litres } \\
0.01 \quad= & \text { light path of the cuvette, in m } \\
630 \quad & \text { absorption coefficient of NADH at } 340 \mathrm{~nm}, \text { in } \mathrm{m}^{2} / \\
& \text { mol }
\end{aligned}
$$

$$
\begin{array}{ll}
10^{-3} & =\text { to refer to } \mu \mathrm{mol} \\
\Delta A / \mathrm{min} & =\text { average absorbance change (decrease) per minute } \\
b & =\text { catalytic concentration }
\end{array}
$$

The average from at least 4 absorbance differences and the factor 1746 were used to calculate factor XIII activity in $\mathrm{U} / 1\left(37^{\circ} \mathrm{C}\right)$. Factor XIII activity (\%) was estimated by using a linear standard plasma calibration curve (for more détails see under results).

\section{Optimized assay}

The NAD reagent was dissolved in a solution containing $\mathrm{l} g / \mathrm{fi}-$ brin aggregation inhibitor in distilled water. Activator reagent (containing $5 \mathrm{mg}$ liophilised fibrin aggregation inhibitor) was reconstituted with $5 \mathrm{ml}$ of the dissolved NADH reagent to give $2 \mathrm{~g} / \mathrm{l}$ fibrin aggiegation inhibitor. The detection reagent was reconstituted with double distilled water and mixed with an equal volume of the reconstituted activator reagent to give the reaction mixture containing $1 \mathrm{~g} / 1$ fibrin aggregation inhibitor. Determination of factor XIII activity was performed as described above. For the reduced sample volume of $50 \mu \mathrm{l}$ the catalytic concentration is obtained as follows:

$$
b[\mathrm{U} / \mathrm{l}]=\frac{\Delta A / \min }{630 \cdot 10^{-3} \cdot 0.01} \cdot \frac{1.05 \cdot 10^{-3}}{0.05 \cdot 10^{-3}}=\Delta \mathrm{A} / \mathrm{min} \cdot 3333
$$

\section{Results}

As described in the literature $(10,11)$, during the first 3 minutes after the start of the reaction the registration curve shows a decrease of absorbance due to the conversion of endogenous ammonia (fig. 1). In plasma samples with normal fibrinogen concentrations, a continuous decrease of the absorbance was observed. The lower the factor XIII activity, the longer the linear period of the reaction (up to 15 to 20 minutes); but with low factor XIII activity, the linear reaction period starts later (fig. 2). Samples from patients with hyperfibrinogenaemia form a clot in the cuvette during the measurement, which makes the interpretation of the results impossible (fig. 3).

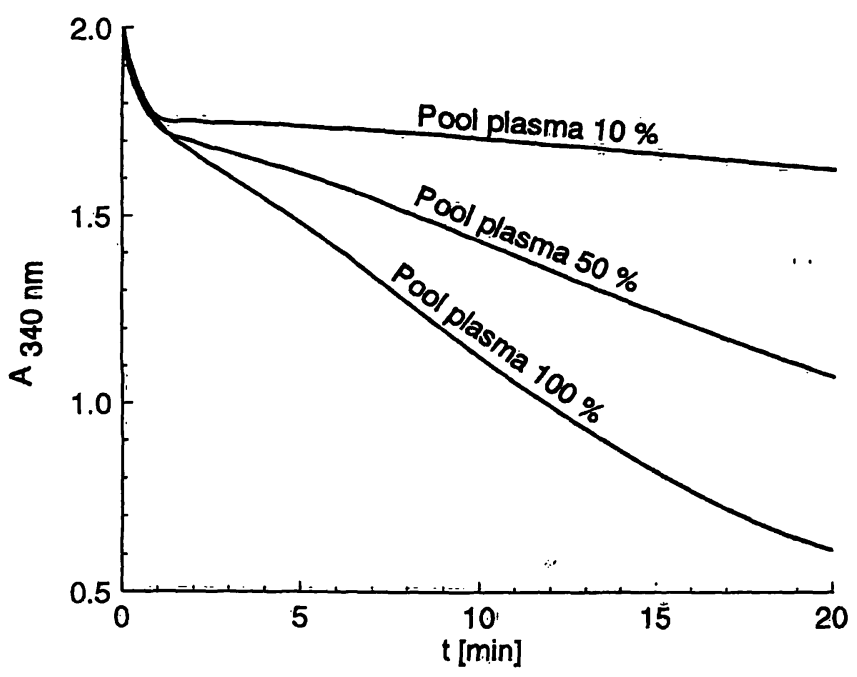

Fig. 1 Factor XIII assay according to Fickenscher. Reaction course of a norrial plasma pool from 10 persons. Fibrin aggregation inhibitor $0.5 \mathrm{~g} / \mathrm{A}, 100 \mu \mathrm{l}$ sample volume. 


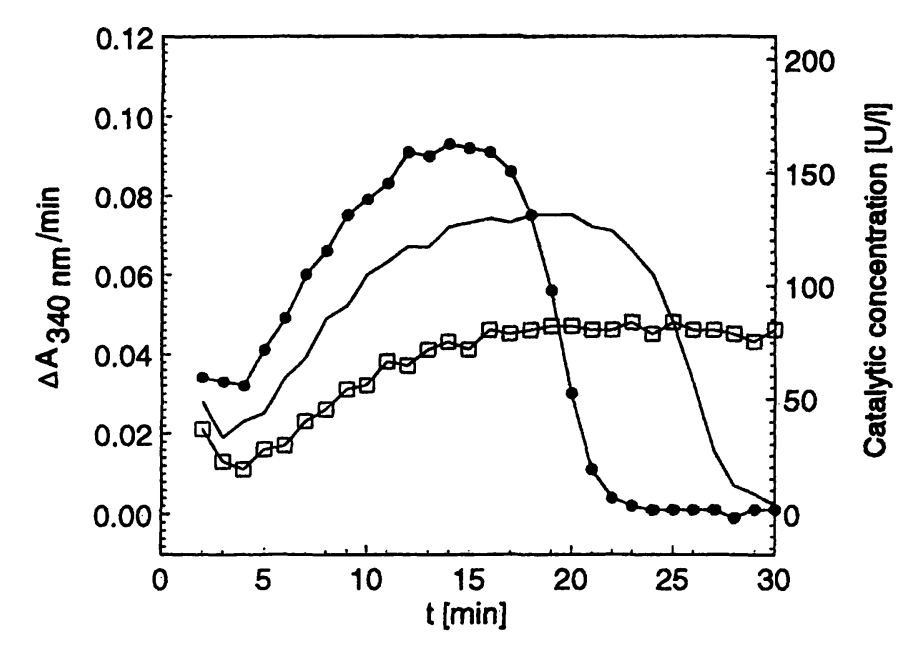

Fig. 2 Factor XIII assay according to Fickenscher. Dependence of the linear time course of factor XIII activity. $200 \%$ of factor XIII was diluted with $154 \mathrm{mmol} / \mathrm{NaCl}$ solution to give 40,80 and $120 \%$. Another dilution step ( $1+1$ with $8 \mathrm{~g} / 1$ factor XIII-free fibrinogen) yielded $-\square-20,-40$ and $-\bullet-60 \%$.

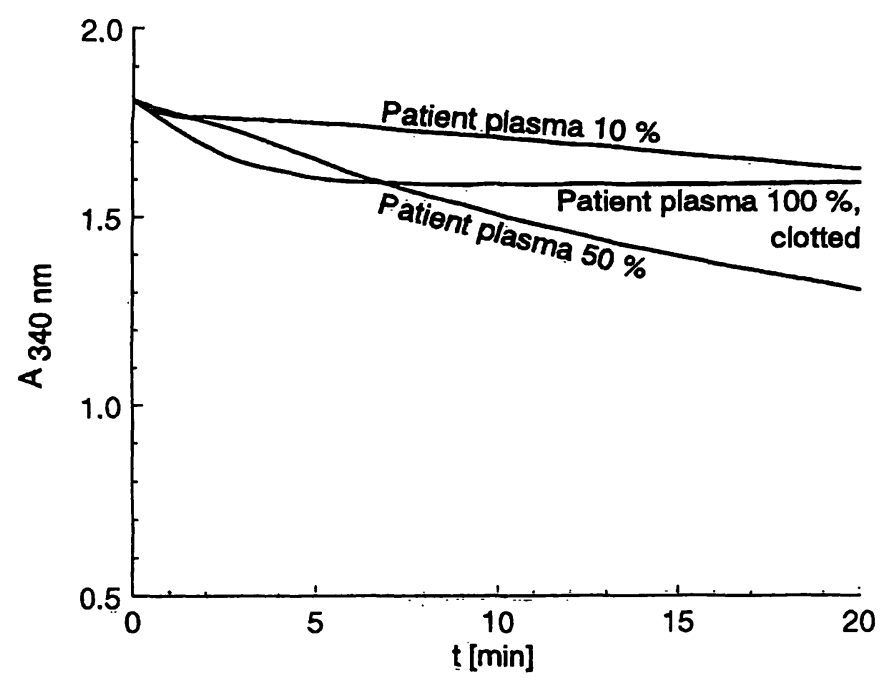

Fig. 3 Factor XIII assay according to Fickenscher. Reaction course of a patient plasma with hyperfibrinogenaemia. Prothrombin ratio 1.05 , thrombin time $15 \mathrm{~s}$, activated prothrombin time $28 \mathrm{~s}$, fibrinogen concentration $8.5 \mathrm{~g} / \mathrm{l}$. Fibrin aggregation inhibitor 0.5 $\mathrm{g} / \mathrm{l}, 100 \mu \mathrm{l}$ sample volume.

The assay was therefore modified by raising the concentration of the fibrin aggregation inhibitor from $0.5 \mathrm{~g} / 1$ to $1.0 \mathrm{~g} / \mathrm{l}$. This had no adverse effect in the determination of a pool plasma from 10 persons (fig. 4); whereas in a patient with hyperfibrinogenaemia the detection of factor XIII activity was improved. After 11 minutes, clot formation simulates an increase of absorbance (fig. 5). With $50 \%$ predilution of the patient sample (in $154 \mathrm{mmol} / 1$ aqueous $\mathrm{NaCl}$ solution) the measured factor XIII activity increased from $97 \mathrm{U} / 1$ in the non-optimized to $133 \mathrm{U} / \mathrm{l}$ in the optimized assay (fig. 3 and 5).

Examination of the dilution limit with the unmodified reagent resulted in a linear measurement range up to $80 \%$ or $82 \mathrm{U} / 1\left(37^{\circ} \mathrm{C}\right)$. The modified version of the test showed an equivalent value. Using $50 \mu$ sample instead of $100 \mu$ lexpands the range of linearity to $140 \%$, corresponding to $128 \mathrm{U} / 1\left(37^{\circ} \mathrm{C}\right.$ ) (fig. 6). The calculation factor changes to 3333 .

In patients with hyperfibrinogenaemia, all samples showed lower activities of factor XIII in the conventional assay. Using a $50 \%$ reduced sample volume, $50 \%$ (3/6) of the patients seemed to have a decreased factor XIII activity of less than $20 \%$. Determination of factor XIII activity with the twofold optimized assay showed normal results in all patients (tab. 1).

The twofold optimized test variant was used to determine the precision data and to determine the reference interval: $50 \mu \mathrm{l}$ sample added to $1000 \mu \mathrm{l}$ detection re-

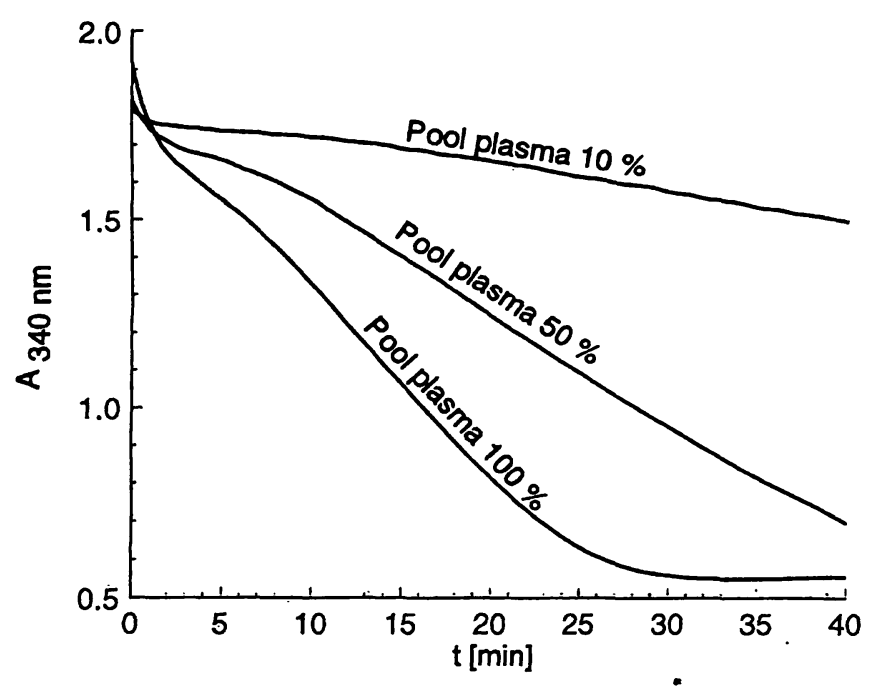

Fig. 4 Factor XIII assay modified. Reaction course of a normal plasma pool from 10 persons. Fibrin aggregation inhibitor $1.0 \mathrm{~g} / \mathrm{l}$. $100 \mu l$ sample volume.

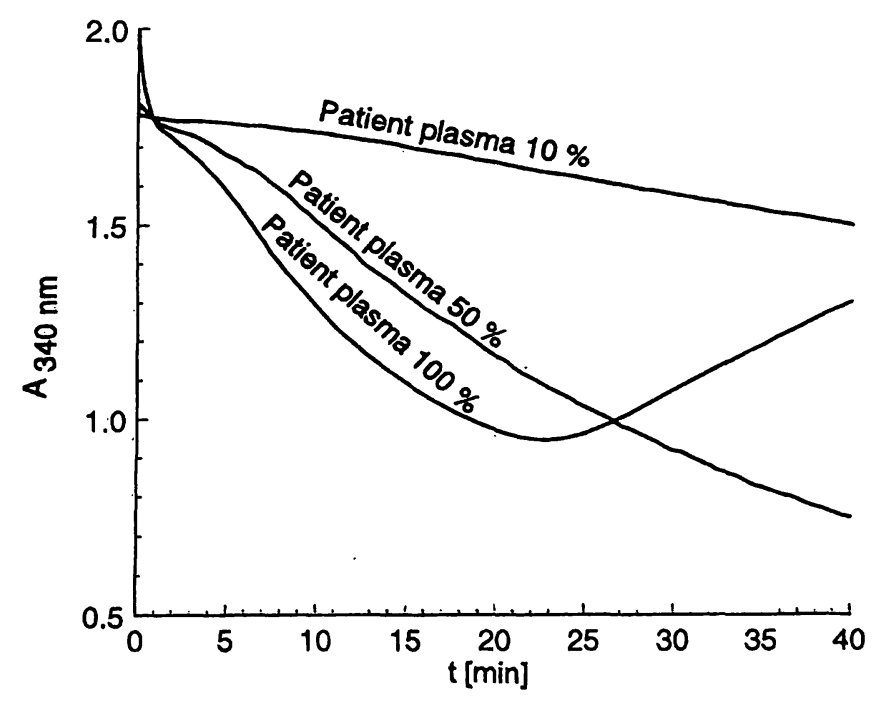

Fig. 5 Factor XIII assay modified. Reaction course of a patient plasma with hyperfibrinogenaemia. Prothrombin ratio 1.05 , thrombin time $15 \mathrm{~s}$, activated prothrombin time $18 \mathrm{~s}$, fibrinogen $8.5 \mathrm{~g} /$. Fibrin aggregation inhibitor $1.0 \mathrm{~g} / \mathrm{l}, 100 \mu \mathrm{l}$ sample volume. 


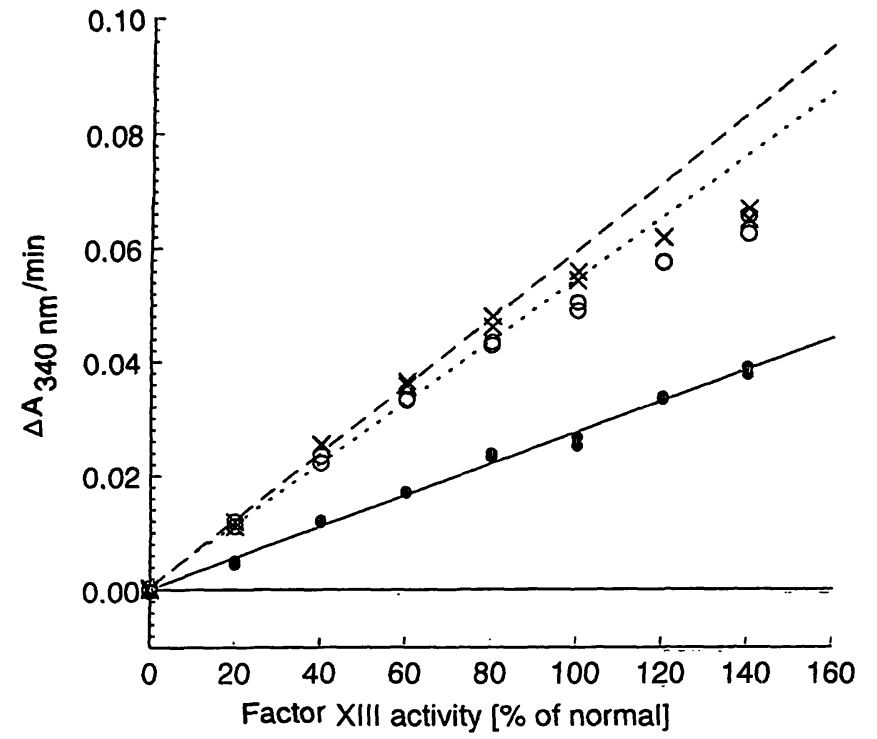

Fig. 6 Serial dilution of a standard plasma $(-x-$ fibrin aggregation inhibitor $0.5 \mathrm{~g} / 1$ [according to Fickenscher], $100 \mu \mathrm{l}$ sample volume; -o- fibrin aggregation inhibitor $1.0 \mathrm{~g} / 1$ [modified assay], $100 \mu \mathrm{l}$ sample volume; - - fibrin aggregation inhibitor $1.0 \mathrm{~g} / \mathrm{l}$, $50 \mu \mathrm{l}$ sample volume [optimized assay]).

Tab. 1 Factor XIII activities in patients with hyperfibrinogenaemia, using the unmodified assay according to Fickenscher with normal and reduced sample volume, and the optimized assay.

\begin{tabular}{|c|c|c|c|c|}
\hline Patient & $\begin{array}{l}\text { Fibrin- } \\
\text { ogen }\end{array}$ & $\begin{array}{l}100 \mu \mathrm{l} \\
\text { sample } \\
\text { volume } \\
0.5 \mathrm{~g} / \mathrm{l} \text { clot } \\
\text { inhibitor } \\
\text { factor XIII } \\
{[\mathrm{U} / \mathrm{l}]}\end{array}$ & $\begin{array}{l}50 \mu \mathrm{l} \\
\text { sample } \\
\text { volume } \\
0.5 \mathrm{~g} / \mathrm{l} \text { clot } \\
\text { inhibitor } \\
\text { factor XIII } \\
\text { [U/l] }\end{array}$ & $\begin{array}{l}50 \mu \mathrm{l} \\
\text { sample } \\
\text { volume } \\
1.0 \mathrm{~g} / \mathrm{l} \text { clot } \\
\text { inhibitor } \\
\text { factor XIII } \\
\text { [U/I] }\end{array}$ \\
\hline 19,828 & 9.4 & 26 & 80 & 151 \\
\hline 20,823 & 9.2 & 5 & 95 & 163 \\
\hline 23,875 & 8.1 & 9 & 96 & 126 \\
\hline 23,881 & 8.6 & 10 & 15 & 89 \\
\hline 24,836 & 8.7 & 4 & 5 & 137 \\
\hline 24,859 & 9.3 & 13 & 9 & 72 \\
\hline
\end{tabular}

agent containing $1.0 \mathrm{~g} / \mathrm{l}$ fibrin aggregation inhibitor. The appropriate period for calculating factor XIII activity from the $\Delta A /$ min was determined (usually between 10 and 40 minutes) for each assay.

The precision was $2.3 \%$ in series and $2.8 \%$ from day to day, for a control plasma with $81 \mathrm{U} / 1\left(37^{\circ} \mathrm{C}\right)$. The corresponding values for a control plasma with $35 \mathrm{U} / 1$ $\left(37^{\circ} \mathrm{C}\right)$ were $4.9 \%$ and $5.8 \%$, respectively. With 100 apparently healthy persons, employees and students of the university, between 19 and 44 years of age, the reference interval ranged from 66 to $142 \mathrm{U} / 1\left(37^{\circ} \mathrm{C}\right)$ or from 73 to $155 \%$, and showed a normal distribution of the values (fig. 7).

\section{Discussion}

The continuous UV test for the determination of factor XIII activity described by Fickenscher et al. (11) represents a significant advance compared with earlier methods. The results shown in this paper demonstrate that the method must be applied critically.

Using a fixed period of incubation (5 to 10 minutes (11, $16,17)$ ) does not lead to correct values. The period of constant reaction rate varies with different factor XIII activities from 4 to 20 minutes. A variable assessment of each single reaction course has to be made (fig. 2).

Furthermore it is shown that the added amount of the fibrin aggregation inhibitor is not sufficient to avoid clot formation in reaction mixtures from patients with hyperfibrinogenaemia. Even a reduced sample volume of $50 \mu \mathrm{l}$, as recommended by the manufacturer (reducing the fibrinogen concentrations to the upper limit of the reference interval) simulates a factor XIII deficiency of $15 \mathrm{U} / 1$ or less in $50 \%(3 / 6)$ of the patients (tab. 1). The authors (11) describe a recovery of $96 \%$ factor XIII with a fibrinogen concentration of $10.5 \mathrm{~g} / 1$. A possible explanation of this finding is that they added artificially purified fibrinogen to pooled plasma and did not analyse samples from patients with hyperfibrinogenaemia. In our study, the results are 2 to 3 -fold higher, the time required to attain a constant reaction rate is longer, and the reaction curve was smoother using purified factor XIII and purified fibrinogen than in a matrix of human plasma (fig. 2) (10).

In the presence of a higher inhibitor concentration, the $\Delta A /$ min values and the resulting measured values of the

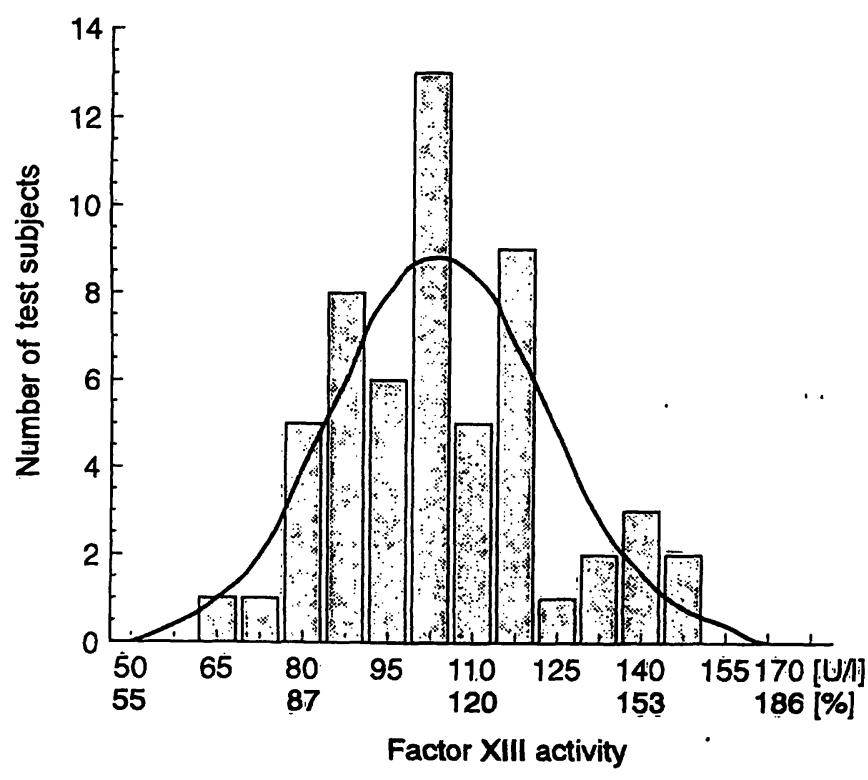

Fig. 7 Factor XIII assay optimized. Determination of the normal range: $104 \pm 38 \mathrm{U} / 1,114 \pm 41 \%(x \pm 2 \mathrm{~s})$ respectively. The reference values were normally distributed. Fibrin aggregation inhibitor $1.0 \mathrm{~g} / \mathrm{l} ; 50 \mu \mathrm{l}$ sample volume. 
enzyme activity show a negligible decrease (fig. 6). This is, however, compensated by determining the reference interval under the same conditions. On the other hand, even in samples from patients with high fibrinogen concentrations, the recorded factor XIII activities are higher than those found with the unmodified test (tab. 1).

Using the original method, we could not confirm the linearity limit of $150 \%$ factor XIII activity described in the literature. We found a value of $80 \%$, corresponding to $82 \mathrm{U} / 1$. A possible explanation is that the other authors analysed the change of absorbance between 5 and 10 minutes, while in the present study the period of constant reaction rate up to at least 20 minutes was used $(11,16,17)$. For low factor XIII activities the 5 to 10 minute interval yields lower results, because the reaction rate is still rising and the constant period is later.

Based on the data of this study a final modification of the method was developed:

\section{References}

1. Robbins, K. C. (1944) A study of conversion of fibrinogen to fibrin. Am. J. Physiol. 142, 581-588.

2. Laki, K. \& Lorand, L. (1948) On the solubility of fibrin clots. Science 108, 280.

3. Jakobsen, F. \& Godal, H. C. (1974) Simple, semiquantitative test for partial factor XIII (FSF) deficiency. Scand. J. Haematol. $12,366-368$.

4. Karges, H. E. \& Heimburger, N. (1976) A rapid screening and quantitative assay of clotting F XIII activity. Int. Congr. Ser. No. 415, Topics in Hematology, Proc. 16th Int. Congr. Hematol., Kyoto Sept. 5-11, pp. 531-533.

5. Janus, T. J., Lewis, S. D., Lorand, L. \& Shafer, J. A. (1983) Promotion of thrombin-catalysed activation of factor XIII by fibrinogen. Biochemistry 22, 6269-6272.

6. Hathaway, W. E. \& Goodnight, S. H. (1993), Abnormalities of fibrinogen. In: Disorders of Hemostasis and Thrombosis (Hathaway, W. E. \& Goodnight, S. H., eds.) 2nd ed., McGrawHill Inc., New York, pp. 167-169.

7. McDonagh, J. (1987) Structure and function of factor XIII. In: Hemostasis and Thrombosis (Colman, R. W., Hirsh, J., Marder, V. J. \& Salzman, E. W., eds.) 2nd ed., Lippincott Company, Philadelphia, pp. 289-300.

8. Hantgan, R. R., Francis, C. W., Scheraga, H. A., Marder, V. J. (1987) Fibrinogen structure and physiology. In: Hemostasis and Thrombosis (Colman, R. W., Hirsh, J., Marder, V. J. \& Salzman, E. W., edș) 2nd ed., Lippincott Company, Philadelphia, pp. 269-288.

9. Musżbek, L., Polgár, J. \& Fésüs, L. (1985) Continuous determination of blood coagulation factor XIII in plasma. Clin. Chem. 31, 35-40.

10. Fickenscher, K. (1993) Berichrom F XIII: Test procedure and the biochemical basis of the kinetic assay. In: Factor XIII, Second International Conference, Marburg, July 9-10, 1991
- The sample volume in the test is reduced from 100 to $50 \mu \mathrm{l}$.

- The concentration of the fibrin aggregation inhibitor in the detection reagent is raised to $1.0 \mathrm{~g} / 1$.

This allows the analysis of samples with factor XIII activities of more than $140 \%$ or $128 \mathrm{U} / 1\left(37^{\circ} \mathrm{C}\right)$ and with elevated fibrinogen concentrations with a reduced sensitivity. The reference interval was also slightly higher $(73-155 \%)$ than in other studies $(70-140 \%(11), 67-$ $147 \%(16), 60-133 \%(17))$. An assay with an increased concentration of fibrin aggregation inhibitor will in future be available from the manufacturer.

\section{Acknowledgements}

We thank Mrs. H. Dauwitz and Miss S. Schmitz for their excellent technical assistance, as well as Dr. Becker and Dr. Fickenscher, Behringwerke Marburg, for kindly supplying us with the fibrin aggregation inhibitor and the F XIII-free fibrinogen.

(McDonagh, J., Seitz, R. \& Egbring, R., eds.) Stuttgart: Schattauer, pp. 122-127.

11. Fickenscher, K., Aab, A. \& Stüber, W. (1991) A photometric assay for blood coagulation factor XIII. Thromb. Haemostas. $65,535-540$.

12. Kolmogoroff, N. A. (1941) Confidence limits for an unknown distribution function. Ann. Math. Stat. 12, 461-463.

13. Smirnov, N. V. (1948) Table for estimating the goodness of fit of empirical distributions. Ann. Math. Stat. 19, 279-281.

14. Lilliefors, H. W. (1967) On the Kolmogorov-Smimov test for normality with mean and variance unknown. J. Am. Statist. Assoc. 62, 399-402.

15. Moss, D. W. \& Henderson, A. R. (1994) Enzymes. In: Tietz' Textbook of Clinical Chemistry (Burtis, C. A. \& Ashwood, E. R., eds.) 2nd ed., W. B. Saunders Company, Philadelphia, pp. $735-896$.

16. van Wersch, J. W. J. (1993) Analytical and clinical utility of a photometric assay of blood coagulation factor XIII. Eur. J. Clin. Chem. Clin. Biochem. 31, 467-471.

17. Solleder, E., Demuth, D., Pfeiffer, C., Bomhard, M., Mayer, J., Brauer, P., Keller, F., Grün, J., Fickenscher, K. \& Wagner, C. (1992) Klinische Prüfung eines neuen photometrischen Tests zur Bestimmung der Faktor XIII-Aktivität im Plasma. Lab. Med. 16, 48-53.

Dr. med. Michael Heins
Institut für Klinische Chemie und
Laboratoriumsdiagnostik
Medizinische Einrichtungen der
Heinrich-Heine-Universität Düsseldorf
Moorenstraße 5
D-40001 Düsseldorf
Germany




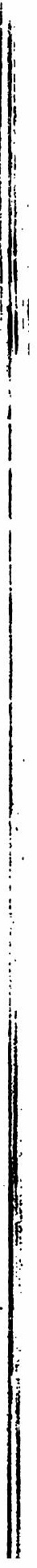

